\section{A COURSE ON LIBRARY BUILDINGS, SUMMER 1967}

In the regular summer session (June 22 through August 10), the graduate library school of Indiana University will give a course on the planning of buildings for colleges and small public libraries. The course will include the preliminary survey of needs, the selection of a site, the preparation of a written program, space relationships within the building, and problems of lighting, heating, and air-conditioning.

The course will be taught by Donald Thompson, librarian of Wabash College. Mr. Thompson has acted as a consultant in the planning of more than twenty college and public library buildings and is the author of several journal articles about library buildings.

Pre-registration is required; students who are not already enrolled in the graduate library school may obtain application blanks by writing to Miss Catherine Cole, Administrative Assistant, Graduate Library School, Education Building, Indiana University 47401, before May 15, 1967. Enrollment will be limited.

MANUSCRIPTS LIBRARIANS

A group of librarians interested in the administration of manuscript collections will hold an organizational meeting on Tuesday, June 27,

\section{UNIVERSITY OF LETHBRIDGE Lethbridge, Alberta, Canada}

The newly-established University of Lethbridge requires qualified librarians in ACQUISITIONS, CATALOGUING, SERIALS and REFERENCE Divisions of the University of Lethbridge.

Salary commensurate with experience and qualifications. Numerous fringe benefits available.

Send applications, curriculum vitae, confidential letters from three referees, and copies of academic records to

Dr. R. J. Leskiw

Acting President

The University of Lethbridge

Lethbridge, Alberta, CANADA at 8:30 p.m. in San Francisco during the annual conference of ALA. They will discuss the desirability of petitioning ACRL for subsection status within its Subject Specialists Section. Persons with interest in this subject may learn more by corresponding with Mrs. Arline Custer, Head, Manuscripts Section, Library of Congress, or Richard C. Berner, Curator of Manuscripts, Library, University of Washington, Seattle.

In his correspondence, Mr. Berner stated that "administrators of manuscript collections stand professionally in two fields, as librarians and/or archivists. Yet they are of little influence in either.

"Perhaps you share a view with me and others that administrators of manuscript collections need an organizational medium that will do at least two things:

1. Establish a forum through which we can exchange ideas, develop a consensus on theory and practice, and address other common problems;

2. Establish a dialogue between us and library administrators, since it is within the administrative context of librarians that most of us work."

The following are some problems regarding manuscript collections that need attention now.

1. Discussion and agreement on methods of arranging and describing manuscripts. Both the L.C. code for "cataloging" manuscripts and the new Anglo-American code would seem premature. If we had existed as a group, we might have affected their promulgation. We should, now, at least direct attention to them.

2. The National Historical Publications Commission microfilming project has posed problems concerning manuscripts on microfilm that no one group is addressing. No group is more keenly aware of these special problems than are manuscript administrators.

3. Cooperative collecting programs for important historical materials that few repositories can either store or process, e.g., business records, particularly of large firms or of an industry. This will entail cooperation of both librarians and archivists; manuscript administrators are a suitable liaison because they stand with a foot in each profession.

4. Formal training needs to be included in library school curricula to acquaint librarians, in general, with manuscript work, and to impart theory and techniques to aspirant curators.

\section{ACADEMIC STATUS}

The Academic Council of Texas A\&M University recently approved full faculty status and academic rank for the professional members of the university library staff. Rank designations will be accorded effective with the beginning of the $1967 / 68$ fiscal year. 